\title{
培養液へのヨウ素添加がトマト，ホウレンソウの生育およびヨウ素蓄積に及ぼす影響
}

\author{
権田か扮り ${ }^{1 *}$ ・山口秀幸 ${ }^{2} \cdot$ 丸尾 達 ${ }^{3}$ ・篠原 $\quad$ 温 $^{3}$ \\ 1 千葉大学大学院自然科学研究科 $263-0022$ 千葉市稲毛区弥生町 \\ 2 関東天然瓦斯開発株式会社 297-8550 茂原市茂原 \\ 3 千葉大学園芸学部 271-8510 松戸市松戸
}

\section{Effects of Iodine on Growth and Iodine Absorption of Hydroponically Grown Tomato and Spinach}

\author{
Kaori Gonda ${ }^{1 *}$, Hideyuki Yamaguchi ${ }^{2}$, Toru Maruo ${ }^{3}$ and Yutaka Shinohara ${ }^{3}$ \\ ${ }^{\prime}$ Graduate school of science and technology, Chiba University, Inage, Chiba 263-0022 \\ ${ }^{2}$ Kanto Natural Gas Development Co., Ltd., Mobara, Chiba 297-8550 \\ ${ }^{3}$ Faculty of horticulture, Chiba University, Matsudo, Chiba 271-8510
}

\begin{abstract}
The effects of $\mathrm{I}^{-}$and $\mathrm{IO}_{3}^{-}$on the growth and iodine absorption of tomato and spinach plants were investigated using a non-recirculating hydroponic system. Tomato and spinach plants were grown under 4 treatments; containing iodine $\mathrm{I}^{-} 0.1 \mathrm{mM}, \mathrm{I}^{-} 0.2 \mathrm{mM}$, $\mathrm{IO}_{3}^{-} 0.2 \mathrm{mM}$ and $0 \mathrm{mM}$ (control) for tomato, and $\mathrm{I}^{-} 0.05 \mathrm{mM}, \mathrm{I}^{-} 0.1 \mathrm{mM}, \mathrm{IO}_{3}^{-} 0.1 \mathrm{mM}$ and $0 \mathrm{mM}$ (control) for spinach. The results indicated that $\mathrm{I}^{-}$treatment was more toxic to plants than $\mathrm{IO}_{3}^{-}$. $\mathrm{I}^{-}$treatments reduced the absorption of nutrient solution. Spinach was more sensitive to iodine than tomato. Spinach grown with a higher $\mathrm{I}^{-}$concentration showed symptoms of necrosis and leaf abscission. Based on these findings, tomato and spinach showed clear differences between their sensitivity to iodine. Further research will be required to achieve the final goal of using iodine as the disinfectant for hydroponic systems while avoiding toxicity to plants. In both species, iodine was found in high concentrations in leaf tissue. Therefore, a leafy vegetable like spinach might be a suitable crop to increase dietary iodine intake. Similarly, tomato fruits were found to accumulate iodine, thus, this crop might also contribute to achieving that objective.
\end{abstract}

Key Words : disinfectant, hydroponics, iodate, iodide, iodine enriched food

キーワード : 殺菌剤, 養液栽培, ヨウ化物イオン, ヨウ素富化食品, ヨウ素酸イオン

\section{緒言}

ヨウ素は, 世界の生産量の約 4 割が日本で生産されている 数少ない国産天然資源であり, 様々な分野においてヨウ素の 利用方法が研究されている. 例えば, ヨウ素は幅広い殺菌作 用を持つため医薬品などに利用され, 最近では, 使用が禁止 された臭化メチルの代替品としてのヨウ化メチル利用や養 液栽培に打ける殺菌剂としてのヨウ素利用をはじめ, 農業 分野でも利用方法が検討されている（Gan・Yates, 1996; Mackowiak ら，2005）。しかし，ヨウ素はイネの赤枯れ病を 引き颃こすなど, 植物の生育に悪影響を及ぼすことも報告さ れている（Mackowiak・Grossl, 1999; Watanabe・Tensho, 1970; Zhu 5，2003）。 また, ヨウ素 $\left(\mathrm{I}_{2}\right)$ は, 養液栽培において殺 菌剂として使用する場合には培養液成分などと反応してヨ ウ化物イオン $\left(\mathrm{I}^{-}\right)$に変化すること, 土畩溶液中では大部分 がヨウ素酸イオン $\left(\mathrm{IO}_{3}^{-}\right)$の形態で存在することが知られて

2006 年 5 月 15 日 受付. 2006 年 9 月 8 日 受理.

* Corresponding author. E-mail: gonkamo@hotmail.com
いる. したがって，ヨウ素が植物の生育に及ぼす影響を明ら かにするためには, 濃度だけでなく形態の影響についても調 査する必要がある. 一方，ヨウ素は動物にとっては必須の元 素であることから，食物を通してのヨウ素栄養強化を目的 に, イネなどを対象としたヨウ素富化食品の研究が行われて いる（Mackowiak・Grossl, 1999; Muramatsu ら，1989）。しか し, 吸収されたヨウ素の多くは葉や根に蓄積し, 子実中のヨ ウ素はごくわずかであるため, ヨウ素富化食品として充分な 結果は得られていない，一方でZhu ら（2003）が，ホウレ ンソウを用いた研究に扔いて, 地上部に多くのヨウ素が蓄積 されることを示していることから, 野菜, 特に葉を食用とす る葉菜類は, ヨウ素富化食品として利用できる可能性がより 高いと考えられる. 本研究では, ヨウ素が植物の生育に及ぼ す影響抏よび植物体中のヨウ素濃度を明らかにすることを 目的とし, 異なる濃度のヨウ素イオン $\left(\mathrm{I}^{-}, \mathrm{IO}_{3}^{-}\right)$を添加し た培養液でトマトとホウレンソウの養液栽培を行った.

\section{材料および方法}

$$
\text { トマトは, “桃太郎ファイト’を, } 2004 \text { 年 } 4 \text { 月 } 20 \text { 日に }
$$


第 1 表 培養液へのヨウ素添加がトマトの生育に及ぼす影響

\begin{tabular}{|c|c|c|c|c|c|c|c|c|c|}
\hline \multirow{2}{*}{ 処理区 } & \multicolumn{3}{|c|}{ 葉長（cm） } & \multicolumn{3}{|c|}{ 葉幅（cm） } & \multicolumn{3}{|c|}{ 葉色（SPAD） } \\
\hline & 第 1 果房 ${ }^{z}$ & 第 2 果房 ${ }^{z}$ & 第 3 果房 ${ }^{z}$ & 第 1 果房 & 第 2 果房 & 第 3 果房 & 第 1 果房 & 第 2 果房 & 第 3 果房 \\
\hline control & $35.0 \mathrm{a}^{\mathrm{y}}$ & $35.5 \mathrm{a}$ & $34.2 \mathrm{a}$ & $29.2 \mathrm{a}$ & $33.2 \mathrm{a}$ & $29.2 \mathrm{a}$ & $51.2 \mathrm{a}$ & $52.4 \mathrm{a}$ & $51.7 \mathrm{ab}$ \\
\hline $\mathrm{I}^{-} 0.1 \mathrm{mM}$ & $34.3 \mathrm{a}$ & $35.2 \mathrm{a}$ & $35.5 \mathrm{a}$ & $28.3 \mathrm{a}$ & $33.8 \mathrm{a}$ & $30.2 \mathrm{a}$ & $50.1 \mathrm{a}$ & $49.3 \mathrm{a}$ & $51.8 \mathrm{ab}$ \\
\hline $\mathrm{I}^{-} 0.2 \mathrm{mM}$ & $35.0 \mathrm{a}$ & $35.5 \mathrm{a}$ & $34.0 \mathrm{a}$ & $30.3 \mathrm{a}$ & $32.5 \mathrm{a}$ & $28.8 \mathrm{a}$ & $48.8 \mathrm{a}$ & $50.5 \mathrm{a}$ & $49.7 \mathrm{~b}$ \\
\hline $\mathrm{IO}_{3}^{-} 0.2 \mathrm{mM}$ & $33.2 \mathrm{a}$ & $34.3 \mathrm{a}$ & $33.3 \mathrm{a}$ & $28.8 \mathrm{a}$ & $31.7 \mathrm{a}$ & $29.8 \mathrm{a}$ & $50.7 \mathrm{a}$ & $49.2 \mathrm{a}$ & $53.0 \mathrm{a}$ \\
\hline
\end{tabular}

$\mathrm{z}$ 果房直下の葉

y 縦に異なるアルファベット間には Tukey 法により 5\%水準で有意差あり

第 2 表＼cjkstart培養液へのヨウ素添加がホウレンソウの生育に及ぼ す影響

\begin{tabular}{lrrrr}
\hline \hline \multirow{2}{*}{ 処理区 } & \multicolumn{3}{c}{ 生体重 $(\mathrm{g})$} \\
\cline { 2 - 4 } & \multicolumn{1}{c}{ 葉身 } & \multicolumn{1}{c}{ 葉柄 } & \multicolumn{1}{c}{ 根 } & \\
\hline control & $20.6 \mathrm{a}^{\mathrm{z}}$ & $14.2 \mathrm{a}$ & $14.6 \mathrm{a}$ & $14.6 \mathrm{a}$ \\
$\mathrm{I}^{-} 0.05 \mathrm{mM}$ & $17.8 \mathrm{~b}$ & $12.1 \mathrm{~b}$ & $10.8 \mathrm{~b}$ & $12.8 \mathrm{~b}$ \\
$\mathrm{I}^{-} 0.1 \mathrm{mM}$ & $9.2 \mathrm{c}$ & $6.2 \mathrm{c}$ & $3.4 \mathrm{c}$ & $9.8 \mathrm{c}$ \\
$\mathrm{IO}_{3}^{-} 0.1 \mathrm{mM}$ & $18.3 \mathrm{~b}$ & $12.3 \mathrm{~b}$ & $10.9 \mathrm{~b}$ & $13.2 \mathrm{~b}$ \\
\hline
\end{tabular}

z縦に異なるアルファベット間には Tukey 法により 5\%水準 で有意差あり

ロックウール粒状綿を充填した 50 穴セルトレイに播種し た. 5 月 21 日に焼成珪藻土を充填した 12 号ポットに鉢上 ゲし，各処理区 20 株ずつを株間 $20 \mathrm{~cm}$ で定植した. 6 月 29 日に $\mathrm{I}^{-}, \mathrm{IO}_{3}^{-}$添加処理を開始し, 7 月 1 日に第 3 果房上 2 葉を残して摘心を行い，7月 27 日に栽培を終了した．培養 液は園試処方 $1 / 2$ 単位液とし, $\mathrm{I}^{-}, \mathrm{IO}_{3}^{-}$を添加しない control 区， $\mathrm{I}^{-} 0.1 \mathrm{mM}$ 区， $\mathrm{I}^{-} 0.2 \mathrm{mM}$ 区， $\mathrm{IO}_{3}^{-} 0.2 \mathrm{mM}$ 区の 4 処理区 を設けた。開花時には, 花房に 100 倍希釈したトマトトー ンを適宜散布した。

ホウレンソウは, ‘ミストラル’を2004 年 12 月 13 日に ロックウール微粒綿を充填した288穴セルトレイに播種し, 2005 年 1 月 17 日にも又殼燻炭を充填した 7.5 号ポットに鉢 上げした。 1 月 28 日に, 各処理区 44 株を株間 $10 \mathrm{~cm}$ で定 植した. 2 月 2 日に $\mathrm{I}^{-}, \mathrm{IO}_{3}^{-}$添加処理を開始し, 4 月 1 日に 栽培を終了した。培養液は太洋ホウレンソウ処方 $\left(\mathrm{NO}_{3}\right.$ $\left.\mathrm{N}: 16, \mathrm{PO}_{4}-\mathrm{P}: 4, \mathrm{~K}: 12, \mathrm{Ca}: 4, \mathrm{Mg}: 4 \mathrm{me} \cdot \mathrm{L}^{-1}\right) 1 / 2$ 単位 液とし， $\mathrm{I}^{-}, \mathrm{IO}_{3}^{-}$を添加しない control 区， $\mathrm{I}^{-} 0.05 \mathrm{mM}$ 区， $\mathrm{I}^{-}$ $0.1 \mathrm{mM}$ 区, $\mathrm{IO}_{3}^{-} 0.1 \mathrm{mM}$ 区の 4 処理区を設けた。栽培中は, 温室内の夜温が $7^{\circ} \mathrm{C}$ 以下にならないよらに温風暖房機で加 温した.

トマト，ホウレンソウのいずれも，栽培はガラス温室で 行った. $\mathrm{I}^{-}, \mathrm{IO}_{3}^{-}$処理区では，それぞれ培養液中に $\mathrm{KI}$ また

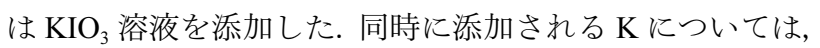
培養液中の $\mathrm{K}$ 濃度と比較して，トマトでは $5 \%$ ，ホウレン ソウでは $1 \%$ 以内と微量であり, 影響はないと考えられた ため, 調整を行わなかった，給液される培養液の $\mathrm{I}^{-}, \mathrm{IO}_{3}^{-}$
濃度を常に一定に保つために非循環式とし，すべての株に 同量の培養液が与えられるよう, 各ポットにエミッターを 設置した点滴式養液栽培装置を作製して給液を行った。給 液量は, 排液量が給液量の 2 割程度になるよう天候に応じ て適宜調節した．排液は処理区ごとに集め，3 日ごとに排 液量を測定し, 同時にサンプリングを行った． 給液量と排 液量の差から, 又かけの吸水量 (以下吸水量)を算出した. また，給排液サンプルの無機成分の分析を行い，ヨウ素お よび無機塩類について, みかけの養分吸収量 (以下吸収量) を算出した.

トマトは，栽培中に 1 週間ごとに生育調査を行い， 1 処 理区 6 株ずつについて, 各果房直下の葉の葉長, 葉幅, 葉 色を測定した。葉色は, 葉緑素計を用いて 1 葉につき無作 為に 4 点を測定し，その平均を測定值とした．栽培終了時 に, 1 処理区 6 株ずつ植物体のサンプリングを行った. ト マトでは, 第 1 果房以下, 第 1 果房から第 2 果房, 第 2 果 房から第 3 果房, 第 3 果房以上の 4 つの部分をそれぞれ葉 身, 葉柄, 茥に分け, さらに根と果実を分析試料とした. ホウレンソウでは，株ごとに葉をばらして，展開順に同じ 枚数になるように3つに分け，新しい葉から順に上位，中 位，下位とし，それぞれの葉身，葉柄と根について分析を

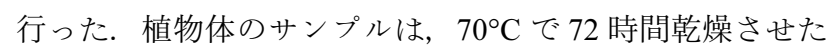
後に粉砕し, フラスコ燃焼法および Leipert 法 (松岡, 1974) を用いて，植物体中に含まれるヨウ素の定量を行った.

\section{結 果}

\section{1. 生育}

第 1,2 表にトマトおよびホウレンソウの栽培終了時の生 育を示した．トマトでは， $\mathrm{I}^{-} 0.2 \mathrm{mM}$ 区で第 1 果房以下执よ び第 3 果房の葉で葉色が低下する傾向が見られたが, 葉色, 葉長, 葉幅ともに control 区との間に有意な差異は認められ なかった．ホウレンソウでは， $\mathrm{I}^{-}, \mathrm{IO}_{3}^{-}$処理区で下位の葉 の黄化や落葉がみられ（データ省略）, 葉数, 生体重は control 区に比べて低下した. 特に $\mathrm{I}^{-} 0.1 \mathrm{mM}$ 区では顕著で あり，根の生育が著しく抑制された． $\mathrm{IO}_{3}^{-}$処理でも control 区に比べて生体重が低下したが, $\mathrm{IO}_{3}^{-} 0.1 \mathrm{mM}$ 区で $\mathrm{I}^{-} 0.05 \mathrm{mM}$ 区と同程度であった。 
第 3 表 培養液へのヨウ素添加がトマトの植物体中ヨウ素濃度に及ぼす影響

\begin{tabular}{llcccc}
\hline \hline \multirow{2}{*}{ 処理区 } & \multicolumn{3}{c}{ 植物体中 I 濃度 $\left(\mathrm{mg} \cdot \mathrm{kg}^{-1} \mathrm{DW}\right)$} \\
\cline { 2 - 6 } & 茎 & 葉柄 & 葉身 & 根 & 果実 \\
\hline control & N.D. ${ }^{\mathrm{z}}$ & N.D. & N.D. & N.D. & N.D. \\
$\mathrm{I}^{-} 0.1 \mathrm{mM}$ & $537 \mathrm{~b}^{\mathrm{y}}$ & $2764 \mathrm{~b}$ & $4692 \mathrm{~b}$ & $1641 \mathrm{a}$ & $305 \mathrm{a}$ \\
$\mathrm{I}^{-} 0.2 \mathrm{mM}$ & $782 \mathrm{a}$ & $4737 \mathrm{a}$ & $9824 \mathrm{a}$ & $1723 \mathrm{a}$ & $388 \mathrm{a}$ \\
$\mathrm{IO}_{3}^{-} 0.2 \mathrm{mM}$ & $646 \mathrm{ab}$ & $2037 \mathrm{c}$ & $5361 \mathrm{~b}$ & $945 \mathrm{~b}$ & $339 \mathrm{a}$ \\
\hline
\end{tabular}

${ }^{\mathrm{z}}$ Not Detected の略

$\mathrm{y}$ 縦に異なるアルファベット間には Tukey 法により 5\%水準で有意差あり

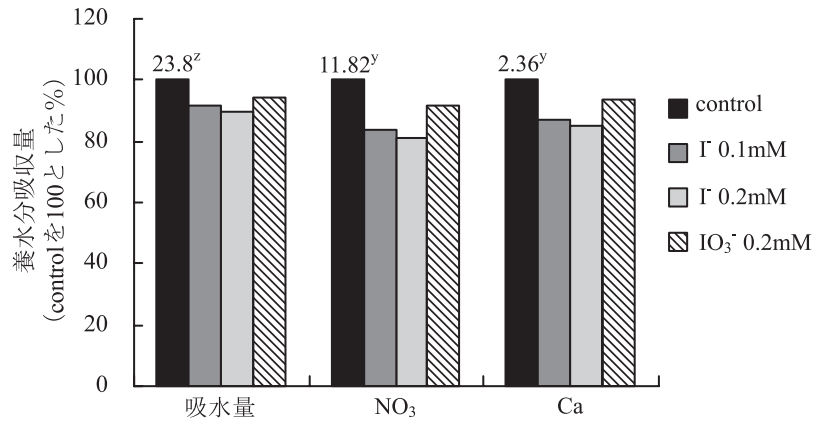

第 1 図 培養液へのヨウ素添加がトマトの養水分吸収量に及 ぼす影響

$\mathrm{z}$ 栽培期間中の総吸水量 $(\mathrm{L} / \mathrm{plant})$

$\mathrm{y}$ 栽培期間中の総吸収量 $(\mathrm{g} / \mathrm{plant})$

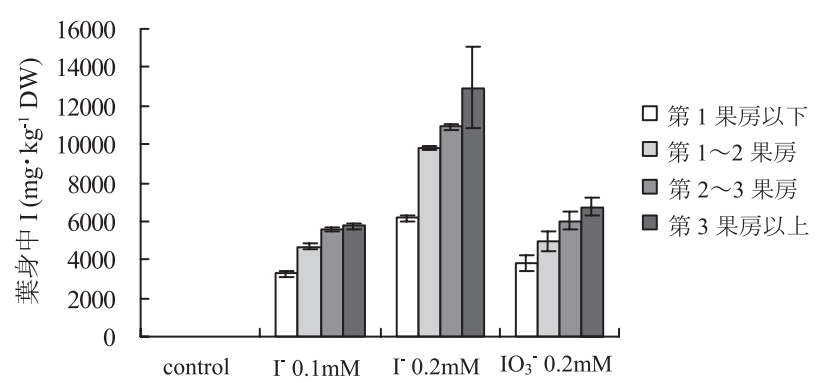

第3 図＼cjkstart培養液へのヨウ素添加がトマト葉身中のヨウ素濃度 に及ぼす影響

図中の縦線は標準誤差（n=5）を表す

\section{2. 養水分吸収量}

第 $1 ， 2$ 図にトマト拈よびホウレンソウの処理開始後 1 か 月間の吸水量および $\mathrm{NO}_{3}, \mathrm{Ca}$ 各成分の吸収量を, control 区 の吸収量を 100 とした割合で示した. トマト，ホウレンソウ のいずれに打いても, I- 処理によって養水分吸収量が低下し たが, $\mathrm{IO}_{3}^{-}$処理では $\mathrm{I}^{-}$処理ほど顕著な影響はみられなかっ た. ホウレンソウはトマトよりも $\mathrm{I}^{-}$処理の影響を強く受け, 吸水量はトマトでは $\mathrm{I}^{-} 0.2 \mathrm{mM}$ 区でも control 区の 90\%程度で あったのに対して，ホウレンソウでは $\mathrm{I}^{-} 0.1 \mathrm{mM}$ 区で control 区の 60\%程度まで低下した。

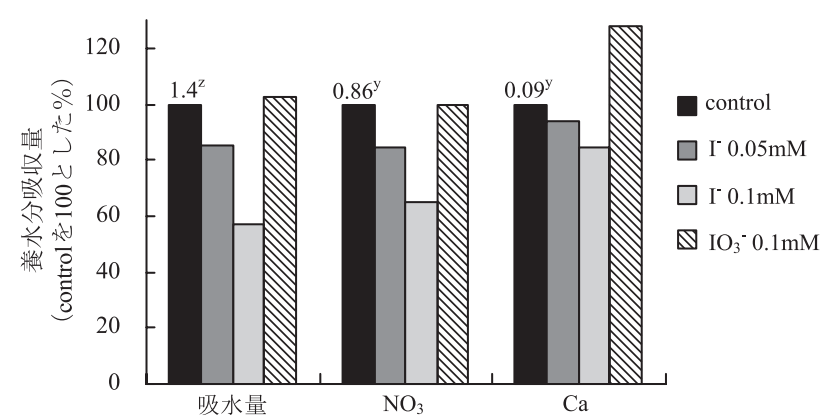

第 2 図培養液へのヨウ素添加がホウレンソウの養水分吸収 量に及ぼす影響

$\mathrm{z}$ 栽培期間中の総吸水量 (L/plant)

$\mathrm{y}$ 栽培期間中の総吸収量 $(\mathrm{g} / \mathrm{plant})$

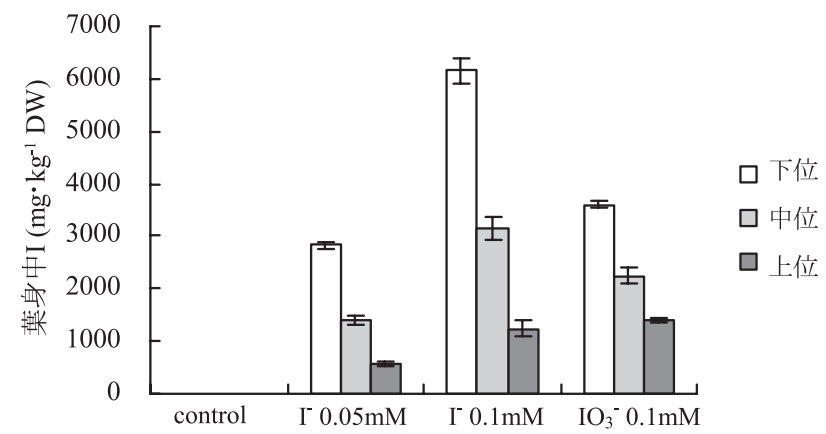

第 4 図 培養液へのヨウ素添加がホウレンソウ葉身中のヨウ 素濃度に及ぼす影響

図中の縦線は標準誤差（n=5）を表す

\section{3. 植物体中ヨウ素濃度}

第 3, 4 表に栽培終了時の部位ごとの植物体中ヨウ素濃 度，第 3, 4 図に葉身中のヨウ素濃度を示した。 トマト，ホ ウレンソウのいずれも, control 区の植物からはヨウ素は検 出されなかった． $\mathrm{I}^{-}$処理では培養液中の $\mathrm{I}^{-}$濃度の上昇によ り植物体中のヨウ素濃度も上昇したが, $\mathrm{IO}_{3}^{-}$処理区の植物 体中ヨウ素濃度はその $1 / 2$ の濃度の $\mathrm{I}^{-}$処理区とほぼ同等で あった．部位別に見ると，トマト，ホウレンソウのいずれ も葉身中のヨウ素濃度が高く, トマトでは可食部である果 実中のヨウ素濃度は, 他の部位に比べて低濃度であった。 
第 4 表 培養液へのヨウ素添加がホウレンソウの植物体中ヨ ウ素濃度に及活す影響

\begin{tabular}{lccc}
\hline \hline \multirow{2}{*}{ 処理区 } & \multicolumn{3}{c}{ 植物体中 I濃度 $\left(\mathrm{mg} \cdot \mathrm{kg}^{-1} \mathrm{DW}\right)$} \\
\cline { 2 - 4 } & 葉柄 & 葉身 & 根 \\
\hline control & N.D. $^{\mathrm{z}}$ & N.D. & N.D. \\
$\mathrm{I}^{-} 0.05 \mathrm{mM}$ & $683 \mathrm{~b}^{\mathrm{y}}$ & $1599 \mathrm{c}$ & $732 \mathrm{~b}$ \\
$\mathrm{I}^{-} 0.1 \mathrm{mM}$ & $2617 \mathrm{a}$ & $3541 \mathrm{a}$ & $1746 \mathrm{a}$ \\
$\mathrm{IO}_{3}^{-} 0.1 \mathrm{mM}$ & $814 \mathrm{~b}$ & $2495 \mathrm{~b}$ & $1075 \mathrm{~b}$ \\
\hline
\end{tabular}

${ }^{\mathrm{z}}$ Not Detected の略

y 縦に異なるアルファベット間には Tukey 法により $5 \%$ 水準 で有意差あり

葉身中ヨウ素濃度は，トマトでは上位の葉ほど，ホウレン ソウでは下位の葉ほど高かった。

\section{考察}

Borst Pouwels (1961) は, 栽培環境中の微量 (0.02-0.2 mg・ $\left.\mathrm{kg}^{-1}\right)$ の $\mathrm{I}^{-}$および $\mathrm{IO}_{3}^{-}$が，いくつかの植物の生育を促進す ることを報告しているが，本実験では，高濃度（10 $\mu \mathrm{M}$ 以 上)の $\mathrm{I}^{-}$が植物の生育に悪影響を及ぼすという Mackowiak・ Grossl (1999), Zhu ら（2003）と同様の結果を得た。 これ らの報告では, $\mathrm{IO}_{3}^{-}$処理では $\mathrm{I}^{-}$処理に比べて生育に悪影響 が出にくいことが示されているが, 本実験でも $\mathrm{IO}_{3}^{-}$処理区 の植物は, 同濃度の $\mathrm{I}^{-}$処理区の植物に比べて植物体中ヨゥ 素濃度が低く, 生育阻害の程度も小さかった。 植物が高濃 度のヨウ素を蓄積すると, 光合成阻害などにより葉の黄化 や落葉が起こる（Mynett・Wain; 1973）ことが報告されてお り，本実験でも，ホウレンソウで下位の葉の黄化や落葉が みられた（データ省略）。また $\mathrm{I}^{-}$処理により, 養水分吸収 量はトマトよりもホウレンソウで著しく減少した. 培養液 中から消失した $\mathrm{I}^{-}$のち, 植物体中に蓄積されているヨウ 素の割合を算出したところ, ホウレンソウではほぼ $100 \%$ が 植物体中に蓄積されていたのに対し，トマトでは $60 \%$ と低

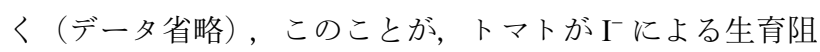
害を受けにくい原因のひとつとなっている可能性も考えら れた. 培養液中の $\mathrm{I}^{-}$および $\mathrm{IO}_{3}^{-}$と培地の間には反応性がな いことが予備実験に抏いて確認されているため, 検出され なかったヨウ素の一部は, 一度植物に吸収された後にガス 化して空気中に放出されている可能性があると思われた. また, トマトはホウレンソウよりも高濃度のヨウ素を葉身 中に蓄積しているにもかかわらず，葉の黄化や落葉などの 症状が皃とんど見られなかったことから，ヨウ素に対する 感受性には植物種間で差があると思われる.

ヨウ素を養液栽培システムの殺菌剂として使用する場 合, $3 \mathrm{ppm}$ 程度の低濃度でも充分な殺菌効果が得られると いら報告がある（小粥ら，2004）が，そのすべてが $\mathrm{I}^{-} に$ 変 化したと考えても, 本実験の $0.05 \mathrm{mM}$ （約 $6.3 \mathrm{ppm）よりも}$ 低濃度であるため, 植物の生育には影響を与えずに充分な 殺菌効果を得ることが可能であると考えられる。しかし，
循環式の養液栽培では, 殺菌の回数を重ねるごとに培養液 中の $\mathrm{I}^{-}$濃度が高まる打それがあることから, 殺菌処理直後 に培養液中の $\mathrm{I}_{2}$ および $\mathrm{I}^{-}$の大部分を取り除き, 培養液中の $\mathrm{I}^{-}$濃度を低く維持する技術の開発が必要である.

成人の 1 日あたりのヨウ素所要量は $0.15 \mathrm{mg}$, 許容上限 摂取量は $3 \mathrm{mg}$ 程度とされている（健康・栄養情報研究会; 1999). 植物体中のヨウ素濃度は, 葉身部で他の部位に比べ て高くなっていたため, 葉を食用とする葉菜類は，ヨウ素 富化作物としての利用が期待できると考えられた.しかし， ホウレンソウの $\mathrm{I}^{-} 0.1 \mathrm{mM}$ 区では，地上部中のヨウ素含有 量は生体重 $100 \mathrm{~g}$ あたり約 $50 \mathrm{mg}$ であり，10 g 摂取しただ けでも上限值を大きく上回ることから, 逆にヨウ素が高濃 度になりすぎる可能性が高く，より慎重な検討が必要であ ると考えられた。トマトでは，いずれのヨウ素添加区にお いても果実中のヨウ素濃度は他の部位に比べて低く, 生体 重 $100 \mathrm{~g}$ あたり約 $20 \mathrm{mg} \cdot \mathrm{kg}^{-1}$ であった. このことから $100 \mathrm{~g}$ のトマトを毎日 1 個食べることで, 十分な量のヨウ素を摂 取することができ， ヨウ素富化食品としての利用が可能で あると考えられた。

本実験では，トマトでは上位の葉ほど，ホウレンソウで は下位の葉ほどヨウ素濃度が高かったが，その理由として $\mathrm{I}^{-}$処理開始時期における植物の生育段階の違いが関係して いる可能性が考えられる. Herrettら（1962）は，ヨウ素は 主に蒸散流によって運ばれ，その後ほとんど転流しないこ とを報告している. 本実験に打いて, 摘心時から処理を行っ たトマトではすべての葉が同期間のヨウ素処理を受けたた め, 日照条件がよく蒸散の盛んな上位の葉で比較的高濃度 のヨウ素が検出されたが，一方のホウレンソウでは，先に 展開した下位の葉により多くのヨウ素が蓄積したと考兄ら れた。

本実験では, トマトはヨウ素処理による影響をほとんど 受けなかったが，循環式で長期栽培を行ら場合には，培養 液および植物体中のヨウ素濃度が徐々に高まるおそれがあ り，処理濃度が本実験と同等かそれ以下でも，生育に悪影 響を及ぼす可能性がある。 そのため，ヨウ素富化された果 実を生産するためには，栽培方法やヨウ素処理方法につい て，より詳細な検討が必要である。

\section{摘 要}

$\mathrm{I}^{-}$および $\mathrm{IO}_{3}^{-}$を添加した培養液を用いた養液栽培で, ト マトとホウレンソウを栽培し，ヨウ素が植物の生育に及ぼ す影響扣よび植物体中のヨウ素濃度を調査した． $\mathrm{I}^{-}$処理に より，トマトでは養水分吸収量がわずかに低下したが，生 育には有意な影響は見られなかった。 ホウレンソウでは養 水分吸収量が著しく低下し, 葉数扔よび生体重の低下が見 られたことから，植物によってヨウ素の感受性が異なると 考えられた。養液栽培においてヨウ素を殺菌剤として用い るためには，栽培植物の種類に対応した処理方法を検討す る必要があると考えられた。植物体中のヨウ素濃度は，卜 
マト，ホウレンソウともに葉身部で他の部位に比べて高く なっていたが，トマトでは果実中にもヨウ素が蓄積されて いた。 よって，ホウレンソウ，トマトともに適切な濃度の ヨウ素処理を行らことにより，ヨウ素富化食品としての利 用が可能であると考えられた。

\section{引用文献}

Borst Pauwels, G. W. F. H. 1961. Iodine as a micronutrient for plants. Plant Soil. 14: 377-392.

Gan, J. and S. R. Yates. 1996. Degradation and phase partition of methyl iodine in soil. J. Agric. Food Chem. 44: 4001-4008.

Herrett, R. A., H. H. Hatfield Jr., D. G. Crosby and A. J. Vlitos. 1962. Leaf abscission induced by the iodide ion. Plant Physiol. 37: 358-363.

健康・栄養情報研究会編集. 1999. 第六次改定 日本人の 栄養所要量 食事摂取基準. p. 157. 第一出版株式会社. 東京.

Mackowiak, C. L. and P. R. Grossl. 1999. Iodate and iodide effects on iodine uptake and partitioning in rice (Oryza sativa L.) grown in solution culture. Plant Soil. 212: 135143.

Mackowiak, C. L., P. R. Grossl and K. L. Cook. 2005. Iodine tox- icity in a plant-solution system with and without humic acid. Plant Soil. 269: 141-150.

松岡敬一郎. 1974. ヨウ素総説. p. 221-228. 霞ヶ関出版株 式会社. 東京.

Muramatsu, Y., S. Uchida, M. Sumiya, Y. Ohmomo and H. Obata. 1989. Tracer experiments on transfer of radio-iodine in the soil-Rice plant system. Water Air Soil Pollut. 45: $157-171$.

Mynett, A. and R. L. Wain. 1973. Herbicidal action of iodine: effect on chlorophyll content and photosynthesis in dwarf bean Phaseolus vulgaris. Weed Res. 13: 101-109.

小粥理絵・山口秀幸 - 丸尾 達 - 篠原 温. 2004. ヨウ素 を用いたナス科植物青枯病菌に対する培養液殺菌技術 の開発に関する研究. 園学雑. 73 (別 1) : 280 .

Watanabe, I. and K. Tensho. 1970. Further study on iodine toxicity in relation to "reclamation Akagare" disease of lowland rice. Soil Sci. Plant Nutr. 16: 192-194.

Zhu, Y. G., Y. Z. Huang, Y. Hu and Y. X. Liu. 2003. Iodine uptake by spinach (Spinacia oleracea L.) plants grown in solution culture: effects of iodine species and solution concentrations. Environ. Int. 29: 33-37. 